\title{
LIPID PEROXIDATION DUE TO TRI-VALENT CHROMIUM (CR3) AMONG TANNERY WORKERS
}

\author{
By \\ El Samra G.H., Hussein A.A., Farahat S.A., Samir A.M \\ FROM \\ Department of Industrial Medicine and Occupational Diseases, \\ Faculty of Medicine. Cairo University.
}

\begin{abstract}
Chrome tanning is the most widely used tanning system worldwide because of its advantages. Occupational exposure to chromium among tannery workers is mainly to the inorganic Cr (III) form. Aim of work: The study aimed at monitoring the level of chromium in both blood and urine among tannery workers and clarifying the effect of increased chromium level in the body on the level of free iron in blood and transferrin based on the fact that both chromium and iron compete for binding sites on transferrin protein. Lipid peroxidation was estimated through measuring the level of malondialdehyde (MDA) in blood. Methods : This work has been carried out in five small- to medium-sized Egyptian tanneries, in Misr Al kadema area in Cairo. The study population was composed of an exposed group $(n=50)$ and a matched control group $(n=30)$. Every subject was subjected to estimation of chromium and iron in both blood and urine. Measurement of transferrin , MDA in blood and blood haemoglobin were done. Results: There was significant increase in the level of the measured parameters among the exposed subjects compared to controls except for haemoglobin which was insignificantly lower among the exposed group. There was significant positive correlation between chromium in urine and blood on one hand and free iron in blood and urine and serum MDA on the other. Also there was significant negative correlation between chromium in urine and blood on one hand and haemoglobin on the other.
\end{abstract}


Conclusion: The results suggest that, occupational exposure to $\mathrm{Cr}$ (III) carries the risk of displacement of iron from transferrin by the excess chromium leading to altered iron metabolism and release of free iron. In addition, the study points to the role of excess chromium in initiation of lipid peroxidation process.

Key words: Tanning industry, Cr (III), transferrin, free iron, lipid peroxidation, MDA, haemoglobin

\section{Introduction}

Tanning is the chemical process that converts animal hides and skins into leather. The term hide is used for the skin of large animals e.g. cows or horses, while skin is used for that of small animals e.g. sheep. There is great variation in the scale and types of tanning facilities. Some tanneries are highly mechanized and use closed automatic systems and many chemicals, whereas others still use largely manual work and natural tanning substances with techniques essentially unchanged over centuries (Baker, 1998). Leather tanning and finishing processes can be divided into many stages. Trimming, soaking, fleshing, and unhairing. The first steps of the process, are referred to as the beamhouse operations, bating, pickling, tanning, wringing, and splitting are referred to as tanyard processes and finishing processes include conditioning, staking, dry milling, buffing, spray finishing, and plating (Gupta,1991).

The main distinction between different tanneries is the use of vegetable or chrome tanning. Prior to the 1900s all leather was tanned by vegetable methods. Now, chrome tanning is the most widely used system worldwide, because of the advantages of light color, speed, low cost, and good stability of the resulting leather. Chrome-tanned leather tends to be softer and more pliable, has higher thermal stability, is very stable in water, and takes less time to produce than vegetable-tanned leather. (Kirk -Othmer, 1995).

Chromium forms a number of compounds in various oxidation states. Those of II (chromous), III (chromic) and VI (chromate ) states are most important; the II state is basic, the III state is amphoteric and the VI state is acidic (ATSDR,2000). It has been known to be a micronutrient for mammals for four decades, but progress in elucidating the role of chromium has proceeded slowly. The last five years have seen a flurry of activity in the elucidation of a potential role for trivalent chromium in mammalian carbohydrate and lipid metabolism at a molecular level. The most popular form of chromium in dietary sup- 
plements, is chromium picolinate which is absorbed in a different fashion from dietary chromium. Chromium picolinate, $\mathrm{Cr}$ (pic)3, is remarkably stable; it remains intact for several hours in synthetic gastric juice (Vincent,2000). After absorption, chromium is known to be maintained in the bloodstream bound to transferrin and to be excreted in the urine bound to the oligopeptide chromodulin (Clodfelder and Vincent, 2005)

However, occupational exposure to chromium among tannery workers is mainly to the inorganic $\mathrm{Cr}$ (III) form, or in the protein bound form (leather dust). In the industrial settings, chromium may enter the body through inhalation, oral route or by direct skin contact (Kornhauser et al., 2002).

Shi et al. (1998) demonstrated that chromium (III) could enhance the formation of hydroxyl radicals from superoxide, though to a lesser extent than chromium (VI), suggesting that chromium (III) can act as a catalyst for the Haber-Weiss cycle (hydrogen peroxide break down producing hydroxyl radical).

\section{Aim of the Work}

The aim of the present study was:

(1) Biological monitoring of chromium in blood and urine, in addition to, detection of the impact of chromium level on the iron level in blood and urine and transferrin level.

(2) Assessment of MDA (malondialdehyde), a lipid peroxidation product in blood and urine as a parameter of oxidative stress among tannery workers.

\section{Subjects and Methods}

\section{Subjects:}

This work had been conducted at five small- to medium-sized Egyptian tanneries, in Misr Al kadema area in Cairo, an area which contains most of the big private sector, leather tanning plants in Egypt. This study was performed on two groups, an occupationally exposed group $(n=50)$ and a control group $(n=30)$. The control subjects were randomly selected from the industrial medicine and occupational diseases outpatient clinic in Kasr Al Aini hospital and were never exposed to leather tanning industry area, taking into consideration matching of age, sex, socioeconomic status and smoking habits.

The exposed group was further subdivided according to stages of leather tanning industry into a preparatory group (beamhouse operations), tanning group and finishing group.

* The preparatory group (beamhouse operations) included fifteen workers ( $\mathrm{n}=15)$, who worked in trimming, soaking, fleshing and unhairing of the hides. 
* Tanning group included nineteen workers $(n=19)$, who worked in bating, pickling, tanning (either vegetable or chrome tanning), wringing and splitting of the hides.

* Finishing group included sixteen workers $(n=16)$, who worked in staking, dry milling, buffing, spray finishing and plating.

\section{Methods:}

Both groups were subjected to the following:

\section{Detailed personal, occupational and} medical histories. Smoking index (S.I.) was calculated as current tobacco consumption (cigarette /day) X duration of smoking (yr)/20 (Lange et al., 1990).

\section{Laboratory investigations:}

\section{a] Determination of chromium in blood} and urine:

The samples for blood chromium level were prepared by dilution of $0.5 \mathrm{ml}$ of blood with $2 \mathrm{ml}$ deionized water. The samples of urine were prepared by dilution of $1 \mathrm{ml}$ of urine with $1 \mathrm{ml}$ of deionized water. The chromium in blood and urine were measured by graphite furnace atomic absorption spectrophotometer (Perkin-Elmer model 5100PC, Norwalk, CT).

\section{1-Sample preparation:}

Three per cent butanlol was added to samples and standards to match the carbon content with the aim of ensuring that the ionization efficiency of elements such as chromium is the same in all solutions. TAMA $0.1 \%$ chemicals (Kwasaki city, Japan) supercleaning, (high purity surfactant), was added to maintain a stable emulsion with the diluted sample. HNO3 $0.05 \%$ was added to ensure that the trace elements were maintained in solution and to aid wash out of these elements between samples; the acid concentration was kept to a minimum, otherwise cellular component in blood sample in particular will aggregate.

\section{2-Calibration solution preparation:}

External calibrator for chromium was prepared by serial dilution of parent stock $(1000 \mu \mathrm{g} / \mathrm{ml})$ using the diluents as those used to dilute and prepare the sample.

\section{3-Optimization of technique:}

For reading concentration of both sample and standard (calibrator), first it was important to choose proper wave length, lamp current band pass optimization.

4-Calculation of the results:

By plotting standard curve, the reading of absorbance of sample and calibrator was plotted in semilog curve, the concen- 
tration of $\mathrm{Cr}$ in the sample was interpreted from this standard curve.

\section{b] Determination of iron and transferrin} in blood and iron in urine:

\section{1-Principle of the method:}

The iron was dissociated from transferrin-iron complex in a weakly acid medium. Liberated iron was reduced into the bivalent form by means of ascorbic acid. Ferrous iron gave with Nitro-PAPS (2-(5nitro-2-pyridyl-azo) a colored complex. The intensity of the colored complex formed is in proportion to the iron concentration in the sample. Iron in urine was determined by a similar method.

\section{2-Standard procedure:}

Reagents used were $1.4 \mathrm{~mol} / \mathrm{L}$ of acetate buffer ( $\mathrm{pH} 4.8), 0.04 \mathrm{mmol} / \mathrm{L}$ of $\mathrm{Ni}-$ tro-PAPS with L Ascorbic acid 99.7\%. Iron Cal. (iron aqueous) primary standard $100 \mu \mathrm{g} / \mathrm{dL}$, mixed and incubated for 2 minutes at room temperature, a sensitive iron indicator to produce a blue chromphore absorbed maximally at $595 \mathrm{~nm}$. Read the absorbance of the samples and standard against the blank was read, the color was stable for at least 30 minutes.

c] Malondialdehyde (MDA) in the serum :

Serum MDA was assayed using the standard technique described by Stringer et al., (1989)

\section{Statistical analysis:}

Results were evaluated for each group. Data were compared using Student t test. Analysis of variance (ANOVA) was used for multiple comparisons between the groups. Post-hoc test was then used to study the inter-relation between the different groups. Pearson correlation test was used to correlate between different variables among the exposed groups. The statistical significance was defined as P-value $<0.05$. Computer based statistical package for social sciences (SPSS) for windows 9.1 program was used.

\section{Results}

The study population was composed of 80 male workers presented in two groups, exposed $(\mathrm{n}=50)$ and control $(\mathrm{n}=30)$. Mean \pm SD of age of the exposed group was $36.88 \pm 11.36$ years ranging from (2059) years versus $37.06 \pm 10.15$ years, ranging from (24-57) years among the controls. Mean duration of exposure was 16.04 \pm 8.31 years ranging from (5-37) years. Both groups were matched for age, smoking habits and socioeconomic standard.

Every participant was subjected to estimation of $\mathrm{Cr}$ in blood and urine, iron in blood and urine, transferrin and serum malondialdehyde (MDA). All the mentioned parameters were significantly high- 
er among the exposed group compared to the controls $(\mathrm{P}<0.001)$ (table 1$)$. Measurement of haemoglobin revealed lower levels among the exposed $(14.12 \pm 1.13 \mathrm{~g} / \mathrm{dl})$ versus $13.71 \pm 1.07$ in the controls (table 1) $(\mathrm{P}>0.05)$.The difference between the two groups was statistically not significant.

The exposed group was further subdivided into beamhouse group $(n=15)$, tanning group $(n=19)$ and finishing group $(n=16)$. The three groups were matched in age, duration of work and smoking index (table 2). The three groups were compared as regards the same laboratory parameters. The tanning group was found to have the highest levels $(\mathrm{P}<0.001)$ (table 3,4). Workers in the beamhouse operations had slightly lower levels of MDA in blood, iron in blood and urine and transferrin than workers of the tanning group and the difference was statistically insignificant. The finishing group was found to have the least increase in the mentioned parameters which were significantly lower than those estimated in the two other exposed groups.

Figures $(1,2)$ show the negative significant correlation between haemoglobin $(\mathrm{g} /$ dl) and both $\mathrm{Cr}$ in urine $(\mu \mathrm{g} / \mathrm{g}$ creat $)(\gamma=-$ 0.35, $\mathrm{P}<0.05)$ and $\mathrm{Cr}$ in blood $(\mu \mathrm{g} / \mathrm{l})(\gamma=-$ 303, $\mathrm{P}<0.05)$. Multiple inter-variable correlations revealed highly significant positive correlation between $\mathrm{Cr}$ in blood with serum MDA, iron in blood and urine $(\mathrm{P}<0.001)$ (table 5). There was another negative but insignificant correlation between iron in blood and haemoglobin level $(\gamma=-0.192, P>0.05)$ (figure 3). On the other hand, iron in blood showed significant positive correlation with MDA $(\gamma=0.41$, $\mathrm{P}<0.05$ ) (figure 4). Duration of work in leather tanning industry was not correlated with any of the available $\mathrm{Cr}$ in blood, $\mathrm{Cr}$ in urine or MDA (table 6). 
Table (1): Mean \pm SD of haemoglobin $(\mathrm{g} / \mathrm{dl})$, chromium in blood $(\mu \mathrm{g} / \mathrm{L})$, chromium in urine $(\mu \mathrm{g} / \mathrm{g}$ creat), MDA in blood $(\mu \mathrm{mol} / \mathrm{L})$, iron in blood $(\mu \mathrm{mol} / \mathrm{L})$, iron in urine $(\mu \mathrm{g} / \mathrm{g}$ creat.) and transferrin ( $\mu \mathrm{mol} / \mathrm{L})$ among exposed and control groups.

\begin{tabular}{|l|c|c|c|c|}
\hline \multicolumn{1}{|c|}{ Data } & $\begin{array}{c}\text { Exposed } \\
(\mathrm{n}=50) \\
\text { Mean } \pm \mathrm{SD}\end{array}$ & $\begin{array}{c}\text { Control } \\
(\mathrm{n}=30) \\
\text { Mean } \pm \mathrm{SD}\end{array}$ & t-test & P-value \\
\hline Hemoglobin $\mathrm{g} / \mathrm{dl}$ & $14.12 \pm 1.13$ & $13.71 \pm 1.07$ & 1.58 & $>0.05$ \\
\hline Chromium in blood $\mu \mathrm{g} / \mathrm{L}$ & $4.272 \pm 1.562$ & $1.574 \pm 1.046$ & 8.38 & $<0.001^{*}$ \\
\hline Chromium in urine $\mu \mathrm{g} / \mathrm{g}$ creat. & 3.2711 .366 & $0.888 \pm 0.456$ & 9.23 & $<0.001^{*}$ \\
\hline MDA in blood $\mu \mathrm{mol} / \mathrm{L}$ & $4.852 \pm 1.742$ & $1.392 \pm 0.948$ & 10.00 & $<0.001^{*}$ \\
\hline Iron in blood $\mu \mathrm{mol} / \mathrm{L}$ & $1.459 \pm 0.312$ & $1.094 \pm 0.340$ & 4.89 & $<0.001^{*}$ \\
\hline Iron in urine $\mu \mathrm{g} / \mathrm{g}$ creat. & $9.492 \pm 2.156$ & $7.658 \pm 1.499$ & 4.09 & $<0.001^{*}$ \\
\hline Transferrin $\mu \mathrm{mol} / \mathrm{L}$ & $2.925 \pm 1.101$ & $1.842 \pm 0.641$ & 4.09 & $<0.001^{*}$ \\
\hline
\end{tabular}

*statistically significant

Table (2): Mean \pm SD of age and duration of work among tannery workers in different departments in leather tanning industry

\begin{tabular}{|c|c|c|c|c|c|}
\hline & $\begin{array}{c}\text { Beamhouse } \\
(\text { no=15) } \\
\text { Mean } \pm \text { SD }\end{array}$ & $\begin{array}{c}\text { Tanning } \\
(\text { no=19) } \\
\text { Mean } \pm \text { SD }\end{array}$ & $\begin{array}{c}\text { Finishing } \\
(\text { no=16) } \\
\text { Mean } \pm \text { SD }\end{array}$ & F & -value \\
\hline Age & $41.66 \pm 11.77$ & $34.86 \pm 11.30$ & $35.18 \pm 10.41$ & 1.813 & $>0.05$ \\
\hline Duration of work & $18.66 \pm 8.59$ & $16.42 \pm 9.05$ & $13.12 \pm 6.17$ & 1.812 & $>0.05$ \\
\hline S.I Pack /year & $34.13 \pm 13.77$ & $28.36 \pm 21.97$ & $22.62 \pm 17.21$ & 1.746 & $>0.05$ \\
\hline
\end{tabular}


Table (3): Mean \pm SD haemoglobin $(\mathrm{g} / \mathrm{dl})$, chromium in blood $(\mu \mathrm{g} / \mathrm{L})$, chromium in urine ( $\mu \mathrm{g} / \mathrm{g}$ creat.), MDA in blood $(\mu \mathrm{mol} / \mathrm{L})$, iron in blood $(\mu \mathrm{mol} / \mathrm{L})$, iron in urine $(\mu \mathrm{g} / \mathrm{g}$ creat $)$ and transferrin $(\mu \mathrm{mol} / \mathrm{L})$ among tannery workers in different departments in leather tanning industry

\begin{tabular}{|l|c|c|c|c|c|}
\hline \multicolumn{1}{|c|}{ Variables } & $\begin{array}{c}\text { Beamhouse } \\
(\mathrm{no}=15) \\
\text { Mean } \pm \mathrm{SD}\end{array}$ & $\begin{array}{c}\text { Tanning } \\
(\mathrm{no}=19) \\
\text { Mean } \pm \mathrm{SD}\end{array}$ & $\begin{array}{c}\text { Finishing } \\
(\mathrm{no}=16) \\
\text { Mean } \pm \mathrm{SD}\end{array}$ & $\mathrm{F}$ & p-value \\
\hline Hemoglobin $\mathrm{g} / \mathrm{dl}$ & $14.16 \pm 1.12$ & $13.90 \pm 1.15$ & $14.34 \pm 1.14$ & 0.65 & $>0.05$ \\
\hline $\mathrm{Cr}$ in blood $\mu \mathrm{g} / \mathrm{L}$ & $4.193 \pm 1.690$ & $5.546 \pm 0.695$ & $2.833 \pm 0.679$ & 27.08 & $<0.001$ \\
\hline $\mathrm{Cr}$ in urine $\mu \mathrm{g} / \mathrm{g} \mathrm{creat.}$ & $3.394 \pm 1.086$ & $4.271 \pm 1.033$ & $1.969 \pm 0.788$ & 24.14 & $<0.001$ \\
\hline $\mathrm{MDA}$ in blood $\mu \mathrm{mol} / \mathrm{L}$ & $5.413 \pm 1.576$ & $5.604 \pm 1.456$ & $3.432 \pm 1.365$ & 11.10 & $<0.001$ \\
\hline $\mathrm{Fe}$ in blood $\mu \mathrm{mol} / \mathrm{L}$ & $1.524 \pm 0.273$ & $1.620 \pm 0.237$ & $1.208 \pm 0.278$ & 11.417 & $<0.001$ \\
\hline Fe in urine $\mu \mathrm{g} / \mathrm{g}$ creat. & $9.890 \pm 2.050$ & $10.573 \pm 2.211$ & $7.837 \pm 0.921$ & 10.071 & $<0.001$ \\
\hline Transferrin $\mu \mathrm{mol} / \mathrm{L}$ & $3.188 \pm 1.100$ & $3.452 \pm 0.988$ & $2.055 \pm 0.658$ & 10.55 & $<0.001$ \\
\hline
\end{tabular}

Table (4): Multiple comparison between mean $\pm \mathrm{SD}$ of chromium in blood $(\mu \mathrm{g} / \mathrm{L})$, chromium in urine ( $\mu \mathrm{g} / \mathrm{g}$ creat.), MDA in blood $(\mu \mathrm{mol} / \mathrm{L})$, iron in blood $(\mu \mathrm{mol} / \mathrm{L})$, iron in urine $(\mu \mathrm{g} / \mathrm{g}$ creat.) and transferrin $(\mu \mathrm{mol} / \mathrm{L})$ among tannery workers in different departments in leather tanning industry

\begin{tabular}{|c|c|c|c|c|}
\hline & $\begin{array}{c}\text { Beamhouse } \\
(n=15)\end{array}$ & $\begin{array}{l}\text { Tanning } \\
(\mathrm{n}=19)\end{array}$ & $\begin{array}{c}\text { Finishing } \\
(n=16)\end{array}$ & $\mathrm{p}$-value \\
\hline & Mean \pm SD & Mean \pm SD & Mean \pm SD & \\
\hline \multirow{3}{*}{$\begin{array}{c}\text { Cr in blood } \\
\mu \mathrm{g} / \mathrm{L}\end{array}$} & $4.193 \pm 1.690$ & $5.546 \pm 0.695$ & & $<0.05$ \\
\hline & $4.193 \pm 1.690$ & & $2.833 \pm 0.679$ & $<0.05$ \\
\hline & & $5.546 \pm 0.695$ & $2.833 \pm 0.679$ & $<0.001$ \\
\hline \multirow{3}{*}{$\begin{array}{l}\mathrm{Cr} \text { in urine } \\
\mu \mathrm{g} / \mathrm{g} \text { creat. }\end{array}$} & $3.394 \pm 1.086$ & $4.271 \pm 1.033$ & & $<0.05$ \\
\hline & $3.394 \pm 1.086$ & & $1.969 \pm 0.788$ & $<0.001$ \\
\hline & & $4.271 \pm 1.033$ & $1.969 \pm 0.788$ & $<0.001$ \\
\hline \multirow{3}{*}{$\begin{array}{c}\text { MDA in blood } \\
\mu \mathrm{mol} / \mathrm{L}\end{array}$} & $5.413 \pm 1.576$ & $5.604 \pm 1.456$ & & $>0.05$ \\
\hline & $5.413 \pm 1.576$ & & $3.432 \pm 1.365$ & $<0.001$ \\
\hline & & $5.604 \pm 1.456$ & $3.432 \pm 1.365$ & $<0.001$ \\
\hline \multirow{3}{*}{$\begin{array}{c}\text { Fe in blood } \\
\mu \mathrm{mol} / \mathrm{L}\end{array}$} & $1.524 \pm 0.273$ & $1.620 \pm 0.237$ & & $>0.05$ \\
\hline & $1.524 \pm 0.273$ & & $1.208 \pm 0.278$ & $<0.05$ \\
\hline & & $1.620 \pm 0.237$ & $1.208 \pm 0.278$ & $<0.001$ \\
\hline \multirow{3}{*}{$\begin{array}{l}\text { Fe in urine } \\
\mu \mathrm{g} / \mathrm{g} \text { creat. }\end{array}$} & $9.890 \pm 2.050$ & $10.573 \pm 2.21$ & & $>0.05$ \\
\hline & $9.890 \pm 2.050$ & & $7.837 \pm 0.921$ & $<0.05$ \\
\hline & & $10.573 \pm 2.21$ & $7.837 \pm 0.921$ & $<0.001$ \\
\hline \multirow{3}{*}{$\begin{array}{c}\text { Transferrin } \\
\mu \mathrm{mol} / \mathrm{L}\end{array}$} & $3.188 \pm 1.100$ & $3.452 \pm 0.988$ & & $>0.05$ \\
\hline & $3.188 \pm 1.100$ & & $2.055 \pm 0.658$ & $<0.05$ \\
\hline & $1.524 \pm 0.273$ & $1.620 \pm 0.237$ & & $>0.05$ \\
\hline
\end{tabular}




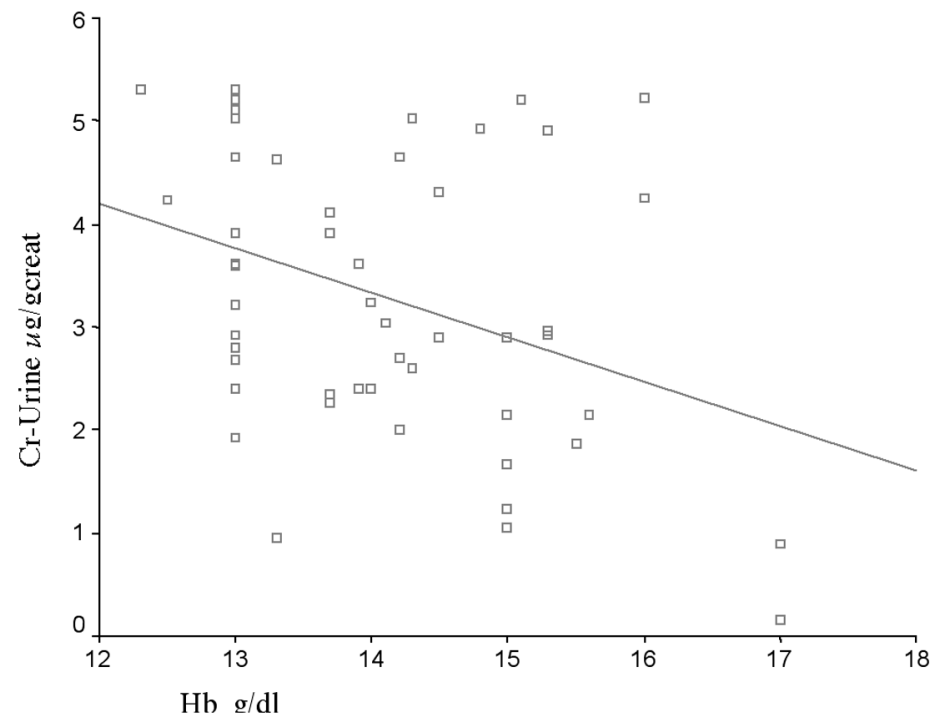

Figure (1): Correlation between chromium in urine and hemoglobin percentage among exposed workers $(\gamma=-0.35, P<0.05)$

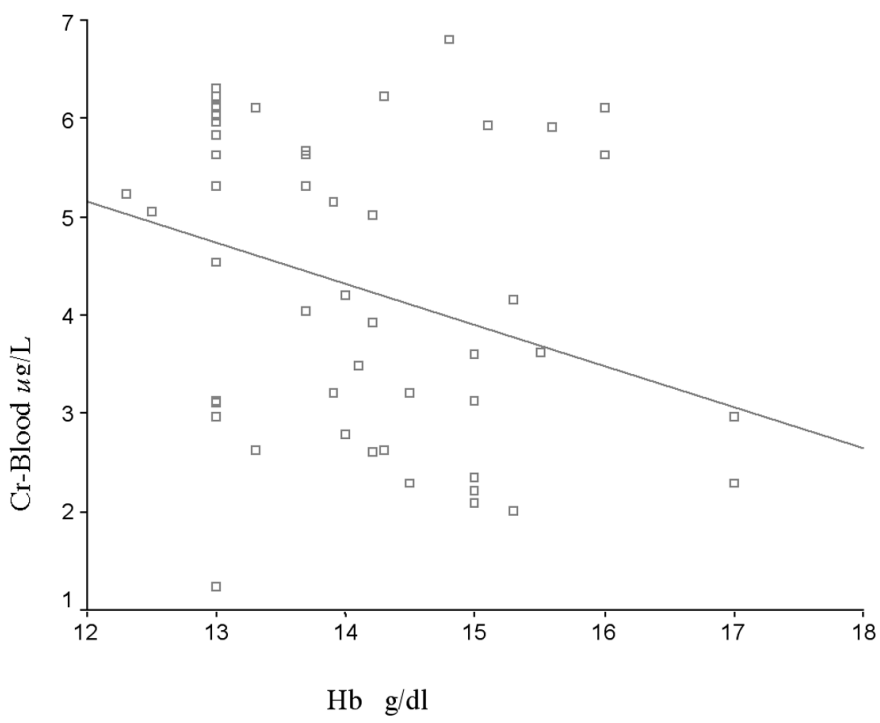

Figure (2): Correlation between chromium in blood and hemoglobin percentage among exposed workers $(\gamma=-0.303, \mathrm{P}<0.05)$ 
Table (5): Correlation between chromium in blood with each of MDA in blood and iron in both blood and urine

\begin{tabular}{|l|c|c|}
\hline Data & $\gamma$ & p-value \\
\hline MDA in blood $\mu \mathrm{mol} / \mathrm{L}$ & 0.490 & $<0.001$ \\
\hline Fe in blood $\mu \mathrm{mol} / \mathrm{L}$ & 0.566 & $<0.001$ \\
\hline Fe in urine $\mu \mathrm{g} / \mathrm{g}$ creat. & 0.546 & $<0.001$ \\
\hline
\end{tabular}

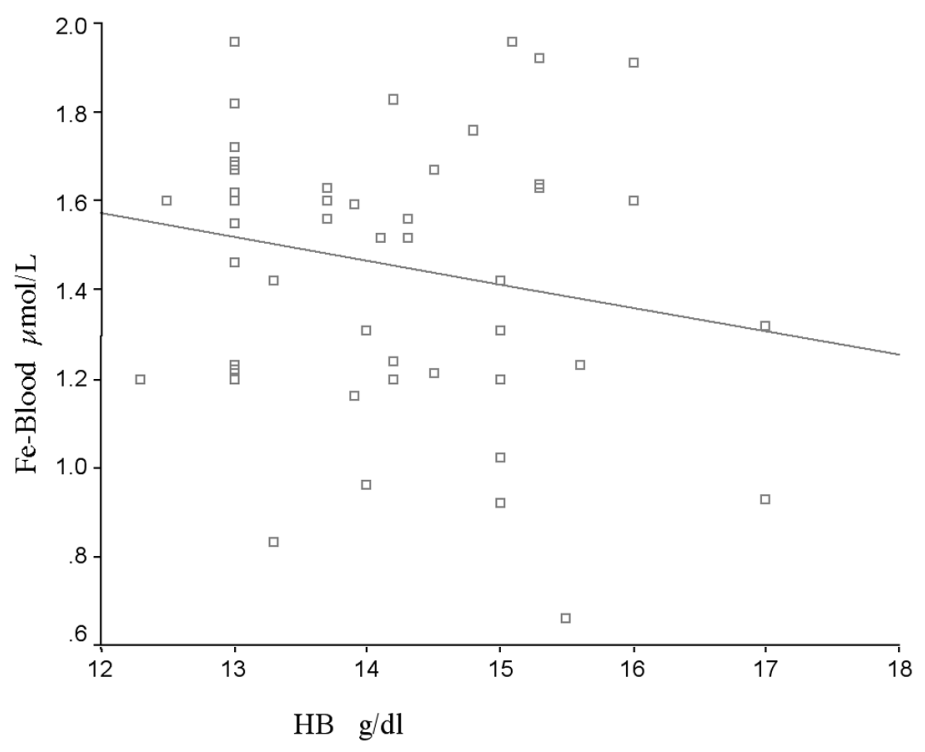

Figure (3): Correlation between iron in blood and hemoglobin percentage among exposed workers $(\gamma=-0.192 \mathrm{P}>0.05)$ 


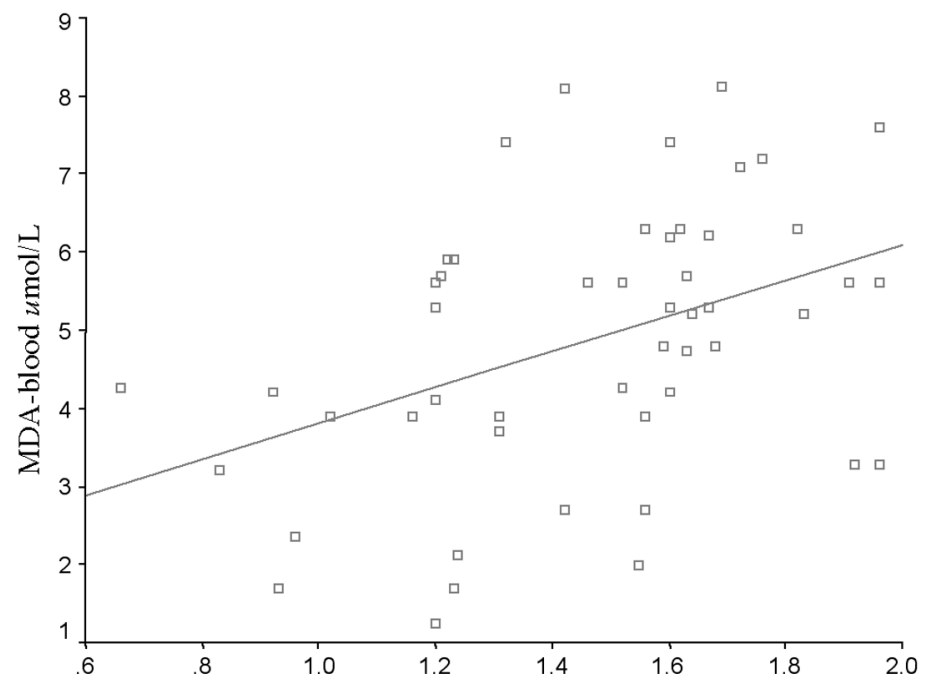

Fe-Blood $\mu \mathrm{mol} / \mathrm{L}$

Figure (4): Correlation between MDA in blood and iron in blood among exposed workers $(\gamma=0.41, \mathrm{P}<0.05)$

Table (6): Correlation between duration of exposure in leather tanning industry with each of chromium levels in blood and urine and MDA levels in blood and iron in blood among exposed workers

\begin{tabular}{|l|c|c|}
\hline \multicolumn{1}{|c|}{ Data } & $\gamma$ & p-value \\
\hline Cr in blood $\mu \mathrm{g} / \mathrm{L}$ & 0.072 & $>0.05^{*}$ \\
\hline Cr in urine $\mu \mathrm{g} / \mathrm{g}$ creat. & 0.12 & $>0.05^{*}$ \\
\hline MDA in blood $\mu \mathrm{mol} / \mathrm{L}$ & 0.19 & $>0.05^{*}$ \\
\hline Iron in blood $\mu \mathrm{mol} / \mathrm{L}$ & 0.022 & $>0.05^{*}$ \\
\hline
\end{tabular}

* statistically insignificant 


\section{Discussion}

Basic chromium (III) sulphate is widely used in the leather tanning industry as the basic tanning agent. The minimum amount of chromium necessary to perform a good tanning is approximately $3 \mathrm{~g}$ of $\mathrm{Cr} 2 \mathrm{O} 3$ for $100 \mathrm{~g}$ of leather (Tavani and Volzone, 1997). If the tannery purchases a hexavalent compound such as sodium chromate or sodium dichromate, this compound must be reduced to a trivalent compound by treatment with sugar and sulphuric acid so that tanning would take place (Hamilton and Hardy 1974). Chromium emissions may occur from chromate reduction, handling of basic chromic sulfate powder, and from the buffing process. At plants that purchase chromic sulfate in powder form, dust containing trivalent chromium may be emitted during storage, handling, and mixing of the dry chromic sulfate. The buffing operation also releases particulates, which may contain chromium (Marshall and Rutland, 1996).

Blood distribution of chromium appears to be divided evenly between plasma and erythrocytes. However, once absorbed, Cr (III) compounds are cleared rapidly from the blood and more slowly from the tissues (Goyer and Clarkson, 2001). Following clearance from the blood, chromium is excreted principally in urine. Secondary excretion of small amounts of ingested metal occurs via bile and feces. Minor routes of excretion are through the skin and via sweat (Cohen and Costa, 1998).

The present study revealed a statistically significant difference between the exposed and control group as regards chromium in blood $(4.272 \pm 1.562$ versus $1.574 \pm 1.046 \mu \mathrm{g} / \mathrm{L})$ and urine $(3.271 \pm 1.366$ versus $0.888 \pm 0.456 \mu \mathrm{g} / \mathrm{gm}$ creat ) (table, 1$)$ $(\mathrm{p}<0.001)$.These results are comparable to those obtained by Medeiros et al., (2003) who investigated levels of blood and urine chromium in the tannery workers. Plasma chromium was higher in tanners $(2.43+/$ 2.11 versus $0.41+/-0.11 \mathrm{microg} / \mathrm{L}$ in controls $\mathrm{P}<0.001)$. Urinary chromium was also higher in tanners compared to controls $(2.63+/-1.62$ versus $0.70+/-0.38$ microg/g creatinine, $\mathrm{P}<0.001$ )

According to Miksche and Lewalter (1997), chromium measurement in urine and whole blood or plasma is indicative of recent total chromium exposure. Urinary chromium excretion reflects absorption over the previous 1 or 2 days only. Therefore, if sufficient time has elapsed for urinary clearance, a negative bio-monitoring result can occur even with injurious past exposure. Additionally, Goyer and Clarkson (2001), reported wide individual varia- 
tion in metabolism and depletion of body burden which limits the value of urinary chromium monitoring.

Further analysis of the results, showed statistically significantly higher levels of chromium in blood and urine among workers in the tanning department than in other departments (table, 3$)(\mathrm{p}<0.001)$. Our findings agree with Kornhauser et al. (2002), who studied three groups of subjects. Group (1) included 15 male tannery workers highly exposed to chromium from tanning and retanning departments. Group (2) included 14 male tannery workers with moderate chromium exposure from dying, drying and finishing departments. Group (3) included 11 healthy, male subjects without direct chromium exposure. Higher serum chromium levels were observed in group one than in the other groups. Urine chromium levels in group (1) were higher than those in controls. In our work, there were greater amounts of cr(III) used in the tanning departments than in the other departments.Many studies demonstrated the similarities between $\mathrm{Cr}$ (III) and $\mathrm{Fe}$ (III) in the term of electrical charge, ion size and competition of the two ions for transferrin binding sites (Clodfelder and Vincent, 2005). Therefore, one of the aims of this study, was to estimate the free iron level in blood and urine in addition to the level of serum transferrin. The study revealed that, there was a statistically significantly higher level of free iron in both blood and urine and serum transferrin among the exposed workers compared to the controls (table,1) $(\mathrm{p}<0.001)$. On comparing different exposed groups as regards the same mentioned parameters, there was a statistically significant difference among workers in the tanning department compared to other departments $(\mathrm{p}<0.001)$ (table 3,4). These results point to the competition of chromium with iron in binding to apotransferrin, thus influencing iron metabolism and its related biochemical parameters and leading to an increase in the level of free iron (III) in blood and urine .

Our findings are supported by a study carried out by Vincent,(2001). The author reported that in vivo administration of chromic ions to mammals orally or by injection resulted in the appearance of chromic ions in the iron-transport protein transferrin. On the other hand, in vitro addition of chromium sources to blood or blood plasma also resulted in the loading of transferrin with $\mathrm{Cr}$ (III). Recently, Racek (2003) reported that, after absorption in the gastrointestinal tract, chromium is most likely transported to cells bound to the plasma protein transferrin. Insulin initiates chromium transport into the cells 
where it is bound to the oligopeptide apochromodulin. This oligopeptide combined with four chromium(III) atoms forms chromodulin, which is important for amplifying the insulin signalling effect.

Another in vivo study showed that total iron binding capacity (TIBC) was reduced by $11 \%$ following daily administration of chromium $(1 \mathrm{mg} / \mathrm{kg})$ for 45 days. Serum ferritin was reduced by $22 \%$ under this condition. Hematocrit and hemoglobin levels were also affected in chromiumtreated animals and were both reduced by 17\% (Ani and Moshtaghie 1992). In the present study, haemoglobin was insignificantly lower among the exposed workers compared to the controls.

The previous results could explain the statistically significant negative correlation between chromium level in both blood and urine versus hemoglobin level (figure $1 \&$ 2) $(p<0.05)$ and the statistically significant positive correlation between chromium level in blood and iron in blood $(\mathrm{p}<0.001)$ suggesting that chromium excess in the organism could increase free iron .

Metal-mediated formation of free radicals causes various modifications to DNA bases, enhanced lipid peroxidation, and altered calcium and sulfhydryl homeostasis. Lipid peroxides, formed by the attack of radicals on polyunsaturated fatty acid resi- dues of phospholipids, can further react with redox metals finally producing mutagenic and carcinogenic malondialdehyde, 4-hydroxynonenal and other exocyclic DNA adducts (Valko et al., 2006). Until recently, $\mathrm{Cr}$ (III) was thought to be relatively nontoxic. However, Ozawa and Hanaki (1990), demonstrated that $\mathrm{Cr}$ (III) can be reduced to $\mathrm{Cr}(\mathrm{II})$, the newly formed $\mathrm{Cr}$ (II) reacts with hydrogen peroxide to produce hydroxyl radical. The resulting hydroxyl radicals are presumably responsible for tissue damaging effects.

In this study, malondialdehyde (MDA) in the blood and urine was used as a marker for lipid peroxidation in tannery workers in an attempt to establish whether the effect of long-term exposure of tannery workers to chromium compounds may initiate lipid peroxidation or not. The current study revealed a statistically significant difference between the exposed and control group as regards the mean values of MDA in blood ( $<<0.001)$ (table,1). Also it was significantly higher among workers in the tanning department compared to other departments $(\mathrm{p}<0.001)$ (table 3,4).

Our findings are in resemblance to those of Gromadzinska et al. (1996), where the concentration of selenium and thiobarbituric acid reactive substances (TBARS) and activity of glutathione per- 
oxidase (GSH-Px) were determined in blood of 34 workers in a tannery in Gniezno, Poland, who worked in an area containing chromium compounds. Decreased Selenium (Se) concentration in whole blood and blood plasma and elevated TBARS concentration in blood plasma were found in the whole group of investigated tanners as compared to controls. Tanners working in areas with high chromium concentrations had a statistically significant decrease in Se concentration in blood and plasma and decreased urinary excretion of this microelement as compared with other tanners. This may be confirmed by the observed statistically significant increase in TBARS concentration, which seems to be a manifestation of increased lipid peroxidation in blood plasma of tannery workers exposed to chromium compounds. The high level of TBARS in the blood of tanners could not be attributed to their exposure to chromium compounds alone, but concentration or activity of antioxidants in plasma should be carefully analyzed; nutritional antioxidant supplementation might be introduced for the purposes of prevention.

Another study by Huang et al. (1999) included 25 chrome-plating factory workers and a reference group of 28 control subjects. The whole-blood and urinary chromium concentrations, MDA, and the activities of protective enzymes superoxide dismutase (SOD), glutathione peroxide (GPX), and catalase (CAT)) were measured. They found that the concentrations of both chromium and MDA in blood and urine were significantly higher in the chromium-exposed workers. The activities of superoxide dismutase (SOD), glutathione peroxidase (GPX), and catalase (CAT) were not markedly different when controls and exposed workers were compared. Data suggest that MDA may be used as a biomarker for occupational chromium effect whereas, antioxidant enzyme activities are not suitable markers for chromium exposure.

The statistically significant positive correlation between MDA in blood and chromium level in blood $(\mathrm{p}<0.001)$ (table, 5) is consistent with Huang et al. (1999), who found a similar result suggesting evidence of an index of oxidative damage.

Contrarily, when Elis et al. (2001) measured plasma lipid oxidation and antioxidant levels in 11 welders chronically exposed to chromium and compared them with levels in 15 matched controls, there was no significant difference between the groups as regards lipid peroxidation and total plasma antioxidant status. However, the small numbers of subjects limit the power of their preliminary study. 
Normally, iron is an essential mineral for normal cellular physiology, but an excess can result in cell injury. The role of iron in the initiation of lipid peroxidation has been reviewed by Gogvadze et al. (2003) who stated that, for iron to facilitate the formation of reactive oxygen species via Fenton reaction, it must be in a free or catalytically active form. For this reason, the amount of iron within the cell is carefully regulated in order to provide an adequate level of a micronutrient while preventing its accumulation and toxicity. A major mechanism for the regulation of iron homeostasis relies on the posttranscriptional control of ferritin and transferrin receptor mRNAs, which are recognized by two cytoplasmic iron regulatory proteins (IRP-1 and IRP-2) that modulate their translation and stability, respectively (Cairo et al., 2002) .

Baykan et al. (2001) investigated iron status and its relationships with lipid peroxidation in patients with acute myocardial infarction (MI). They measured the levels of plasma iron, transferrin (TF), cardiac enzymes, and erythrocyte malondialdehyde (e-MDA) in those patients on admission and on the 1st, 3rd 5th, 7th, 15th, 45th post-MI day and investigated the variations of these parameters in acute MI. There was an association of higher iron status with increased lipid peroxidation on the 1st post Ml day which decreased after the 3rd day.

In another study by Armutcu et al. (2004), the effects of occupational iron exposure on serum iron, serum superoxide dismutase (SOD), a free radical scavenger, and plasma malondialdehyde (MDA), were investigated in Turkish iron miners, office workers and healthy control subjects. Serum iron levels in both miner and office workers groups were higher than those of healthy controls $(\mathrm{p}<0.05)$. There were higher mean values of plasma MDA levels in both iron miners and office workers compared to controls $\quad(\mathrm{p}<0.05)$. Serum SOD activity in the miner group was lower than that of controls $(\mathrm{p}<0.05)$. These changes in MDA metabolism may be due to iron-induced lipid peroxidation in the blood and related body compartments.

Expectedly, there was a statistically significant positive correlation between MDA in blood and iron in blood $(\mathrm{p}<0.05)$ which is consistent with Armutcu et al. (2004) and Baykan et al., (2001).

Table (6) shows that there is no correlation between the duration of exposure in tanning industry and chromium level in blood or urine $(p>0.05)$. This could be explained by the fact that chromium has 
no cumulative effect in the body. This agrees with Saner et al. (1984), who found no correlations between the duration of exposure to chromium on one hand and hair and urinary chromium values among tannery workers on the other. Nevertheless, the high values observed in workers with short exposures, shows that chromium is readily absorbed through the respiratory system.

Our findings also agree with those of Simpson and Gibson (1992), who measured concentrations of $\mathrm{Cr}$ in hair, serum, and urine of men who were previously employed in the leather tanning industry. Concentrations of $\mathrm{Cr}$ in hair and serum were significantly lower than corresponding values obtained during their employment and were comparable to levels obtained for controls in a previous study. These results suggest that Cr III absorbed during employment in the leather tanning industry does not result in long-term elevation of $\mathrm{Cr}$ concentrations in the body.

In the light of the previous results we can suggest that urinary or blood chromium can be used as indicator of chromium exposure among tannery workers in leather tanning industry. Additionally, hemoglobin, serum iron, total iron binding capacity and transferrein levels are recommended for monitoring the effect of elevated blood chromium in tannery workers on iron and hemoglobin metabolism. Nutritional antioxidants supplementation is recommended based on the elevated indices of oxidative damage induced by occupational exposure to chromium.

\section{References}

1. Ani M and Moshtaghie AA (1992): The effect of chromium on parameters related to iron metabolism. Biol. Trace Elem. Res. 32:57-64

2. ATSDR (2000): Case studies in Environmental Medicine. Chromium toxicity. Course: SS3048.

3. http://www.atsdr.cdc.gov/HEC/CSEM/chromium.

4. Armutcu F, Gurel A and Aker A (2004): Serum iron concentrations, lipid peroxidation and superoxide dismutase activity in Turkish iron miners. Environ. Geochem. Health 26(1):1-4.

5. Baker DB (1998): Tanning and Leather Finishing, in: Stellman J Mager ed. Encyclopadedia of Occupational Health and Safety 4th edition. Vol. (3). International Labour Office, Geneva p. 88.3-4.

6. Baykan M, Celik U, Orem A, Malkoc M, Erdol C, Baykan EC, Orem C and Karahan B (2001): Iron status and its relationship with lipid peroxidation in patients with acute myocardial infarction. Acta. Cardiol. 56(5):277-81.

7. Cairo G, Recalcati S, Pietrangelo A and Minotti $G$ (2002): The iron regulatory proteins: targets and modulators of free radical reactions and oxidative damage. Free Radic. Biol. Med. 32 (12):1237-43 . 
8. Campbell WW, Beard JL, Davey SL and Evans WJ (1997): Chromium picolinate supplementation and resistive training by older men: effects on iron -status and hematological indexes. Am. J. Clin. Nutr. 66: 944-9.

9. Clodfelder BJ and Vincent JB (2005): The timedependent transport of chromium in adult rats from the bloodstream to the urine. J Biol Inorg Chem. 10(4):383-93.

10. Cohen MD and Costa M (1998): Chromium Compounds, Chapter (74), in: William N Rom ed. Environmental and Occupational Medicine, 3rd edition. Lippincott Raven Publishers, Philadelphia. p. 1045-55.

11. Elis A, Froom P, Ninio A, Cahana L, Lishner M (2001): Employee exposure to chromium and plasma lipid oxidation. Int. J. Occup. Environ. Health 7(3):206-8.

12. Gogvadze V, Walter PB and Ames BN (2003): The role of $\mathrm{Fe} 2+$-induced lipid peroxidation in the initiation of the mitochondrial permeability transition. Arch. Biochem. Biophys. 414 (2):255-60.

13. Goyer RA and Clarkson TW (2001): Chromium. Toxic Effects of Metals, Chapter (23), in: Klaassen CD, ed. Casarett and Doull's: The Basic Science of Poisons, 6th edition. McGrawHill. New York, London, Sydney, Tokyo, Toronto. p. 826-27.

14. Gromadzinska J, Wasowicz W, Sklodowska M, Bulikowski W and Rydzynski K (1996): The influence of atmospheric chromium on selenium content and glutathione peroxidase activity in blood of tannery workers. Environ. Health Perspect. 104(12):1312-16.
15. Gupta VP (1991): Tanning and Leather Finishing, in: Parmeggiani L. ed. Encyclopadedia of Occupational Health and Safety 3rd (revised) ed. Vol. (2). International Labour Office. Geneva.p. 2144-6.

16. Hamilton A and Hardy HL (1974): Chromium, in*** Industrial Toxicology. 3rd ed. Sciences Publishing Group. Inc. USA p. 71- 5.

17. Huang YL, Chen CY, Sheu JY, Chuang IC, Pan JH and Lin TH (1999): Lipid peroxidation in workers exposed to hexavalent chromium. J. Toxicol. Environ. Health 56(4):235-47.

18. Kasprzak KS (1995): Possible role of oxidative damage in metal induced carcinogenesis. Cancer Invest. 13:411-30.

19. Kirk-Othmer (1995): Encyclopedia of Chemical Technology, 4th ed. Vol. 15. John Wiley and Sons, New York. p. 160-177.

20. Kornhauser C, Wrobel K, Malacara JM, Nava LE, Gomez L and Gonzalez R (2002): Possible adverse effects of chromium in occupational exposure of tannery workers. Ind. Health. 40: 207-13.

21. Lange P,Groth S and Morensen G (1990): Decline of lung function related to the type of tobacco smoked and inhaled. Thorax 45(1):22-26.

22. Ozawa T and Hanaki A (1990): Spin-trapping studies on the reactions of $\mathrm{Cr}$ (III) with hydrogen peroxide in the presence of reductions. Biochem. Int. 22:343-52.

23. Marshall TA and Rutland F (1996): Midwest Research Institute, with Environmental Consultant, Leather Industries of America.www.epa.gov/ttnchie1/ap42/ch09/final/ c9s15.pdf. 
24. Medeiros MG, Rodrigues AS, Batoréu MC, Laires A, Rueff J and Zhitkovich A (2003): Elevated levels of DNA-protein cross links and micronuclei in peripheral lymphocytes of tannery workers exposed to trivalent chromium. Mutagenesis 18 (1): 19-24.

25. Miksche LW and Lewalter J (1997): Health surveillance and biological effect monitoring for chromium-exposed workers. Regul. Toxicol. Pharmacol. 26(2):94-9.

26. Racek J (2003): Chromium as an essential element. Cas Lek Cesk. 142(6):335-9.

27. Saner G, Yuzbasiyan V and Cigdem S (1984): Hair chromium concentration and chromium excretion in tannery workers. Br. J. Ind. Med. 41:263-66.

28. Shi X, Dalal NS and Kasprzak KS (1993): Generation of free radicals from hydrogen peroxide and lipid hydroperoxides in the presence of Cr(III). Arch Biochem Biophys 302(1):294291.
29. Simpson JR and Gibson RS (1992): Hair, serum, and urine chromium concentrations in former employees of the leather tanning industry. Biol. Trace Elem. Res. 32:155-159.

30. Stringer MD., Corog PG. and Freeman A. (1989): Lipid peroxidation and atherosclerosis . B.M.J. 281:298 .

31. Tavani EL and Volzone C (1997): Adsorption of $\mathrm{Cr}$ (III) from a tanning wastewater on Kaolinite. J. Soc. Leather Techn. Chem. 81: 143-8.

32. Valko M, Morris H, Cronin MT.(2005): Metals, toxicity and oxidative stress. Curr Med Chem. 12(10):1161-208.

33. Valko M, Rhodes CJ, Moncol J, Izakovic M, Mazur M. (2006): Free radicals, metals and antioxidants in oxidative stress-induced cancer. Chem Biol Interact. 10;160(1):1-40.

34. Vincent JB (2000): The Biochemistry of Chromium. J . Nutrition. 130:715-718. 